Danuta Roszko

Uniwersytet Warszawski

d.roszko@uw.edu.pl

Roman Roszko

Instytut Slawistyki PAN

roman.roszko@ispan.waw.pl

\title{
ŚP. PROFESOR VIOLETTA KOSESKA I JEJ KLUCZOWE TEORIE LINGWISTYCZNE
}

Domine Deus ad te confugio in asperis rebus lacrimas effundo

Infirmtatem nostram respice et fac hominem cum amorem tuum commiscere

\section{PROFESOR DR HAB. VIOLETTA KOSESKA-TOSZEWA \\ 13 grudnia 1940-5 sierpnia 2017}

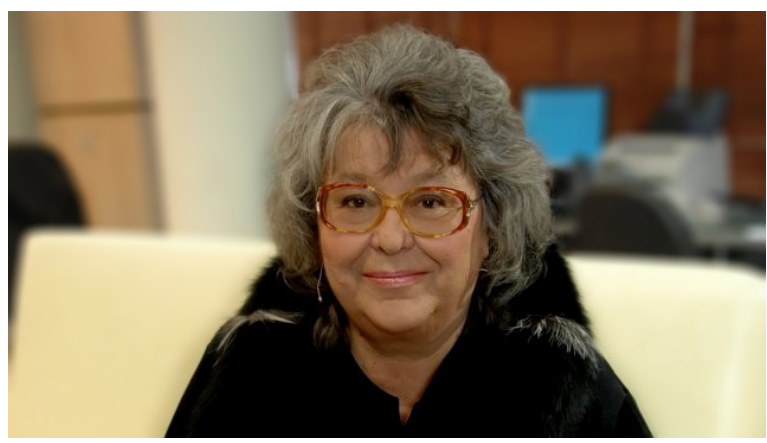

Wybitna polska uczona, językoznawczyni, slawistka, bułgarystka, rusycystka, znakomita organizatorka międzynarodowej współpracy naukowej, twórczyni uznanych w świecie teorii z pogranicza językoznawstwa i logiki, niedościgniona mistrzyni i nauczycielka wielu slawistów, członkini honorowa Bułgarskiej Akademii Nauk oraz wielu gremiów naukowych, autorka ponad 500 prac naukowych, tłumaczka, poliglotka, Bułgarka! 
ŚP. PROFESOR DR HAB. VIOLETTA KOSESKA-TOSZEWA zawsze uważała, że czas przyszły istnieje. Dała temu dobitny wyraz w 7. tomie Gramatyki konfrontatywnej butgarsko-polskiej, w którym opowiedziała się za niedeterministyczną teorią czasu, a to po prostu oznacza..., że przypadki się zdarzają. Dlatego dzisiaj możemy powiedzieć, że zupełnie przypadkiem matka i ciotka śp. Profesor były bułgarystkami, slawistkami, a sama Profesor urodziła się 13 XII 1940 r. w Sofii. Miała czcigodną nauczycielkę języka rosyjskiego, pewną grafinię z Rosji, która nie tylko perfekcyjnie nauczyła Profesor rosyjskiej mowy, lecz również zauroczyła literaturą rosyjską. Profesor Violetta Koseska kończy studia filologiczne w Sofii i zupełnie przypadkiem zakochuje się w Polsce.

Pełna miłości i młodzieńczego zapału przyjeżdża do Warszawy. Tu też przypadkiem staje się szczęśliwą i zarazem ostatnią uczennicą-doktorantką profesora Zdzisława Stiebera. W roku 1970 uzyskuje stopień doktora. Sześć lat później pomyślnie przechodzi proces habilitacyjny. W 1990 roku otrzymuje tytuł profesora nauk humanistycznych. Jest redaktorem naukowym wielu czasopism i serii wydawniczych. Członkiem Polskiego Towarzystwa Językoznawczego i honorowym członkiem Instytutu Języka Bułgarskiego BAN.

Wielokrotnie wyróżniona wysokimi odznaczeniami państwowymi - polskimi i bułgarskimi: Krzyżem Kawalerskim Orderu Odrodzenia Polski, Krzyżem Oficerskim Orderu Odrodzenia Polski, najwyższym odznaczeniem naukowym Bułgarskiej Akademii Nauk - Złotą Odznaką im. Marina Drinowa ze Wstęgą oraz Złotą Odznaką Instytutu Języka Bułgarskiego im. Profesora Lubomira Andrejczina, a także medalami „100 lat Bułgarskiej Akademii Nauk Marin Drinow” i ,50 lat Slawistyki w Polskiej Akademii Nauk”. W roku 2016 zostaje uhonorowana przez Bułgarską Akademię Nauk tytułem doktora honoris causa.

Profesor przez lata z sukcesem kieruje Zespołem Lingwistyki Korpusowej i Semantyki (dalej Zespół-LKiS), z którym uczestniczy w wielu międzynarodowych projektach naukowych, w tym MONDILEX ${ }^{1}$ czy CLARIN-PL 2 .

Profesor Violetta Koseska inicjuje i kieruje wieloma tematami badawczymi we współpracy międzynarodowej Instytutu Slawistyki Polskiej Akademii Nauk z takimi ośrodkami naukowymi jak: Instytut Języka Bułgarskiego Bułgarskiej Akademii Nauk, Instytut Matematyki i Informatyki Bułgarskiej Akademii Nauk,

${ }^{1}$ W latach 2008-2010. Siódmy europejski projekt ramowy (FP7) MONDILEX (Conceptual Modelling of Networking of Centres for High-quality Research in Slavic Lexicography and their Digital Resources). Główny cel projektu - stworzenie ogólnego schematu infrastruktury badawczej, wspierającej badania leksykograficzne języków słowiańskich.

${ }^{2}$ Lata 2013-2016. CLARIN ERIC (Common Language Resources \& Technology Infrastructure, pol. Wspólne zasoby językowe i infrastruktura technologiczna). Podstawowe zadanie Zespołu IS PAN - budowa wielojęzycznych baz pamięci tłumaczeniowych dla języków słowiańskich i bałtyckich o łącznej objętości blisko 17.500 .000 słowoform: A. Kisiel, V. Koseska-Toszewa, N. Kotsyba, J. Satoła-Staśkowiak, W. Sosnowski (2016), Polish-Bulgarian-Russian Parallel Corpus, CLARIN-PL digital repository, http://hdl.handle.net/11321/308; D. Roszko, R. Roszko (2016), PolishLithuanian Parallel Corpus, CLARIN-PL digital repository, http://hdl.handle.net/11321/309. W ramach tego projektu przygotowano również podstawy anotacji semantycznej zasobów korpusowych (V. Koseska, R. Roszko 2015, 2016). 
oraz innymi spoza Bułgarii, w tym z uniwersytetami i akademiami w Chorwacji, Francji, Szwajcarii, Rosji, Słowacji, Słowenii, Stanach Zjednoczonych Ameryki i na Ukrainie.

Jest współzałożycielką i wieloletnim redaktorem naczelnym wielu serii wydawniczych (np. Studiów gramatycznych butgarsko-polskich, Semantyki a konfrontacji językowej) oraz pism takich jak "Slavia Meridionalis” (https://ispan. waw.pl/journals/index.php/sm/issue/view/88) czy „Cognitive Studies | Études cognitives” (https://ispan.waw.pl/journals/index.php/cs-ec/issue/view/98), kierownikiem Studiów Doktoranckich w Instytucie Slawistyki Polskiej Akademii Nauk - w Instytucie, z którym związała całe swe życie naukowe.

Największym dziełem Profesor Violetty Koseskiej jest wielotomowa Gramatyka konfrontatywna butgarsko-polska (1988-2009), wydawana początkowo w Bułgarii (tomy 1-4), następnie w Polsce, licząca łącznie 9 tomów33. Pomysł na nowego typu gramatykę zrodził się w latach 70 . minionego wieku w nieistniejącej już Pracowni Języków Południowosłowiańskich Instytutu Słowianoznawstwa PAN (obecnego Instytutu Slawistyki PAN). Zespół w składzie Kazimierz Feleszko, Violetta Koseska-Toszewa, Małgorzata Korytkowska, Jolanta Mindak i Irena Sawicka opracował nowatorski projekt nowego opisu konfrontatywnego na potrzeby dwóch gramatyk: bułgarsko-polskiej i serbskochorwacko-polskiej (por. Projekt 1984). Warto podkreślić, że to był pierwszy w świecie projekt budowy semantycznej gramatyki konfrontatywnej opartej na logice i semantyce. Ekspertami tegoż projektu w różnych okresach byli wybitni polscy i bułgarscy językoznawcy: Svetomir Ivančev, Ruselina Nicolova, Jordan Penčev, Dina Stanisheva, Kazimierz Feleszko, Stanisław Karolak, Roman Laskowski, Kazimierz Polański i Janusz Siatkowski. Poniżej w skrócie tematyka poszczególnych tomów Gramatyki:

1. fonetyka i fonologia (I. Sawicka, T. Boyadžiev);

2. określoność/nieokreśloność (V. Koseska-Toszewa, G. Gargov);

3. ilość (L. Krumova, R. Roszko);

4. stopień (M. Čoroleeva, A. Petrova-Wasilewicz);

5. kategoria „komunikanta” (I. Gugulanova, P. Barakova, M. Szymański);

6. wybrane typy pozycji predykatowo-argumentowych (M. Korytkowska);

7. modalność - teoria opisu (V. Koseska-Toszewa, V. Maldijeva, J. Penčev);

8. modalność imperceptywna (M. Korytkowska, R. Roszko);

9. modalność hipotetyczna, irrealna, optatywna i imperatywna (V. Maldijeva);

10. modalność interogatywna (M. Korytkowska);

11. semantyczna kategoria czasu (V. Koseska-Toszewa);

12. semantyczna kategoria aspektu (S. Karolak);

13. słowotwórstwo (V. Maldijeva).

${ }^{3}$ Tom 6. Gramatyki liczy 4 obszerne monografie. 


\section{Kluczowe zasługi Profesor dla językoznawstwa}

Profesor Violetta Koseska wnosi do językoznawstwa konfrontatywnego powiew świeżości i naukowego obiektywizmu. Stara się w sposób uporządkowany, spójny i logiczny równocześnie zestawiać wiele języków. Podstawy takiej analizy wykłada w podejściu, które znane jest jako teoretyczne badania konfrontatywne z semantycznym językiem-pośrednikiem. Profesor odrzuca badania ukierunkowane od języka wyjściowego do docelowego. W zamian proponuje konstrukcję wewnętrznie spójnego języka pojęć (czyli języka-pośrednika), a następnie zestawianie każdego języka naturalnego z tymże językiem pojęć. Profesor Violetta Koseska zawsze podkreśla, że język-pośrednik to nie język opisu (metajęzyk).

Kolejnym wielkim dziełem profesor Koseskiej jest teoria kwantyfikacji zakresowej - czyli sformalizowany opis zjawisk określoności i nieokreśloności na poziomie zdania $\mathrm{z}$ wykorzystaniem jednoznacznych $\mathrm{w}$ interpretacji kwantyfikatorów i operatorów logicznych. W pracach nad określonością/nieokreślonością w językach polskim i bułgarskim wprowadza pojęcia silnych i słabych znaczeń kwantyfikacyjnych w powiązaniu z zasięgami oddziaływania i wzajemnego zawierania się kwantyfikatorów, tudzież wyróżnia znaczenia niedopowiedzenia kwantyfikacyjnego i czystej predykacji.

Zastosowanie teorii sieci Petriego w opisie języka naturalnego jest kolejną przełomową dla językoznawstwa metodą analizy i opisu czasu, aspektu i modalności. Rozróżnienie oraz wzajemna konfiguracja stanów i zdarzeń oraz ciągów stanów i zdarzeń zakończonych albo stanem, albo zdarzeniem pozwala interpretować różne wartości aspektualne. Samo zaś odniesienie do stanu wypowiedzi definiuje podstawowe jednostki czasu, takie jak czas teraźniejszy, czas przeszły, czas przyszły i czas ogólny. Natomiast rozwidlenia i rozgałęzienia pozwalają interpretować wartości modalne możliwościowe i koniecznościowe.

Profesor Koseska wprowadza nowe rozumienie gramatyki łączące w sobie tradycyjnie pojmowaną gramatykę i leksykę. Ta bazuje nie na kategoriach morfologicznych lecz na uniwersalnych kategoriach semantycznych, których wykładnikami są środki leksykalne, morfologiczne i syntaktyczne oraz ich wszelkie kombinacje.

Nie zapominajmy o przełomowych dla językoznawstwa konfrontatywnego teoriach - osiągnięciach śp. Profesor Violetty Koseskiej. Wszak żyją one w pracach Jej Uczniów, wzbudzają podziw informatyków w Europie i Ameryce, to jednak - ze stratą dla samego językoznawstwa - nie budzą należytego zainteresowania wśród językoznawców, slawistów. Nie obawiajmy się wysoce sformalizowanego języka opisu - dla dobra nauki oraz pamięci Wielkiej Profesor. 


\section{Wybrane publikacje Profesor Violetty Koseskiej}

\section{6}

Violetta Koseska-Toszewa, Roman Roszko, Języki słowiańskie i litewski w korpusach równoległych Clarin-PL. Studia z Filologii Polskiej i Stowiańskiej, 51, 191-217. DOI: 10.11649/sfps.2016.011.

Wojciech Sosnowski, Violetta Koseska-Toszewa, Anna Kisiel, On the Dictionary of semantic equivalents in Polish, Bulgarian and Russian. Cognitive Studies $\mid$ Études cognitives, 16, 1-11. DOI: 10.11649/cs.2016.001.

Anna Kisiel, Violetta Koseska-Toszewa, Natalia Kotsyba, Joanna Satoła-Staśkowiak, and Wojciech Sosnowski, Polish-Bulgarian-Russian Parallel Corpus, CLARIN-PL digital repository, http://hdl.handle.net/11321/308.

\section{5}

Violetta Koseska-Toszewa, Roman Roszko, On semantic annotation in CLARIN-PL parallel corpora. Cognitive Studies | Etudes cognitives, 15, 211-236. DOI: $10.11649 /$ cs.2015.016.

Ludmila Dimitrova, Violetta Koseska-Toszewa, Digital corpora and their applications in semantic studies and lexicography. Cognitive Studies | Études cognitives, 15, 353-367. DOI: 10.11649/cs.2015.024.

Wojciech Paweł Sosnowski, Violetta Koseska-Toszewa, Multilingualism and dictionaries. Cognitive Studies | Études cognitives, 15, 43-55. DOI: 10.11649/ cs.2015.004.

\section{4}

Ludmila Dimitrova, Violetta Koseska-Toszewa, Danuta Roszko \& Roman Roszko, Trilingual aligned corpus - current state and new applications. Cognitive Studies | Études cognitives, 14, 13-20. DOI: 10.11649/cs.2014.002

Виолетта Косеска-Тошева \& Joanna Satoła-Staśkowiak, Български език, съпоставен с полски и други езици. W III международен конгрес по българистика. Т. 1, Академично Издателство „Проф. Марин Дринов”, София.

Violetta Koseska, Semantics, contrastive linguistics and parallel corpora. Cognitive Studies | Études cognitives, 14, 85-100. DOI: 10.11649/cs.2014.009.

Ludmila Dimitrova, Violetta Koseska, Presentation of the verbs in Bulgarian-Polish electronic dictionary. Cognitive Studies | Études cognitives, 14, 45-54. DOI: $10.11649 /$ cs.2014.005.

Joanna Satoła-Staśkowiak, Violetta Koseska-Toszewa (przy współpracy) Ludmily Dimitrovej, Wspótczesny słownik bułgarsko-polski. Zeszyt 1. Instytut Slawistyki PAN. Warszawa. ISBN 978-83-64031-12-0. 


\section{3}

Violetta Koseska-Toszewa, About certain semantic annotation in parallel corpora. Cognitive Studies | Études cognitives, 13, 67-78. DOI: 10.11649/ cs.2013.004.

Violetta Koseska-Toszewa \& Joanna Satoła-Staśkowiak, O pracy nad słownikami książkowymi i elektronicznymi z językiem bułgarskim. W Л. Крумова-Цветкова, Д. Благоева, С. Колковска (Eds.), 270 години българска академична лексикография. Доклади от Шестата наиионална конференция с международно участие по лексикография и лексикология, София 1, Академично Издателство „Проф. Марин Дринов”, 98-108.

Violetta Koseska-Toszewa, Joanna Satoła-Staśkowiak \& Wojciech Sosnowski, O работе над книжными и электронными словарями с польским, болгарским и русским языками. W Пргкладна лгнгвгстика та лінгвгстичнг технологї̈, MegaLing-2013, 13, НАН України, Укр. мовно-інформ. фонд, Київ, 124-135.

Violetta Koseska-Toszewa, Joanna Satoła-Staśkowiak \& Wojciech Sosnowski, From the Problems of Dictionaries and Multi-lingual Corpora. Cognitive Studies | Études cognitives, 13, 113-122. DOI: 10.11649/cs.2013.007

Ludmila Dimitrova \& Violetta Koseska-Toszewa, Bulgarian-Polish Language Resources (Current State and Future Development). Cognitive Studies | Études cognitives, 13, 161-170. DOI: 10.11649/cs.2013.010 .

Mark Kit \& Violetta Koseska-Toszewa, Dialog between a Lexicographer and a Translator. Cognitive Studies | Études cognitives, 13, 13-24. DOI: 10.11649/ cs.2013.010.

Violetta Koseska-Toszewa, Joanna Satoła-Staśkowiak, Maksim Duszkin, Słownikowe kłopoty (na podstawie tworzonego przez zespół „Polsko-bułgarsko-rosyjskiego słownika”. W Prace Filologiczne, Uniwersytet Warszawski, Fundacja Języka Polskiego, 129-138.

2012

Violetta Koseska-Toszewa, Jeszcze raz o Gramatyce konfrontatywnej bułgarsko-polskiej i jej syntezie polsko-bułgarskiej. W Магията на думите. Езиковедски изследвания в чест на проф. д.ф.н. Лилия Крумова-Цветкова, Академично издателство „Проф. Марин Дринов”, 326-321.

Violetta Koseska-Toszewa, Joanna Satoła-Staśkowiak \& Maksim Duszkin, Теоретические и методологические аспекты создания польско-болгарско-русского словаря. W Прикладна лінгвістика та лінгвістичні технолоziï: MegaLing-2011: 3б. наук. пр., НАН України, Укр. мовно-інформ. Фонд, 210-219.

Виолетта Косеска-Тошева \& Марк Кит, Проблемы междисциплинарности в лингвистике. W Проблемы междисииплинарности в лингвистике, НАН України, Укр. мовно-інформ. Фонд, 1-12. 
Виолетта Косеска-Тошева, Българско-полската съпоставителна граматика и нейното обобщение (втора номинация за най-висока научна награда в Полша). W Юбилеен сборник „70 години Институт за български език при БАН”, Wydawca Академично издателство „Проф. Марин Дринов“, 2012, $151-162$.

Violetta Koseska-Toszewa, Joanna Satoła-Staśkowiak \& Maksim Duszkin, Polish-Bulgarian-Russian, Bulgarian-Polish-Russian or Russian-Bulgarian-Polish Dictionary? Cognitive Studies | Études cognitives", 12, 27-38. DOI: 10.11649/ cs.2012.002.

Violetta Koseska-Toszewa \& Ludmila Dimitrova, Bulgarian-Polish Parallel Digital Corpus and Quantification of Time. Cognitive Studies $\mid \dot{E}$ tudes cognitives, 12, 199-208.

Ludmila Dimitrova, Violetta Koseska-Toszewa \& Joanna Satoła-Staśkowiak, Neologisms in Bilingual Digital Dictionaries (on Example of Bulgarian-Polish Dictionary). Cognitive Studies | Études cognitives, 12, 107-114. DOI: 10.11649/ cs.2012.008.

Violetta Koseska-Toszewa \& Maksim Duszkin, About Meanings as a Rule Not Included in Dictionaries. Cognitive Studies |Études cognitives, 12, 51-56. DOI: $10.11649 / \mathrm{cs} .2012 .004$.

Виолетта Косеска-Тошева, Българско-полска съпоставителна граматика. Т. 7. Семантичната категория време, Академично издателство „Марин Дринов”, София, ss. 154 (9).

Violetta Koseska-Toszewa, O logice i języku naturalnym. Мовознавство, 6, 34-45.

Ludmila Dimitrova, Radovan Garabík, Tomaz Erjavec, Leonid Iomdin, Violetta Koseska-Toszewa \& Volodymyr Shyrokov, Conceptual Scheme for a Research Infrastructure Supporting Resources in Slavic Lexicography, Sofia, Demetra Ltd. Publisher, pp. 131.

Violetta Koseska-Toszewa, Semantyka i konfrontacja językowa (na przykładzie języka polskiego i bułgarskiego). W Слово и словесност, сборник в чест на дои. др Юлия Балтова, ЕМАС.

Violetta Koseska-Toszewa, Definiteness-Iindefiniteness Category and Logical Quantification. Cognitive Studies | Études cognitives, 11, 111-124. DOI: 10.11649/cs.2011.006.

Ludmila Dimitrova, Violetta Koseska-Toszewa, Radovan Garabík, Tomaž Erjavec, Leonid Iomdin \& Volodymyr Shyrokov, Main Results of MONDILEX project. Cognitive Studies | Études cognitives, 11, 265-290. DOI: 10.11649/ cs.2011.017.

Radovan Garabík, Ludmila Dimitrova \& Violetta Koseska-Toszewa, Webpresentation of bilingual corpora (Slovak-Bulgarian and Bulgarian-Polish). Cognitive Studies | Études cognitives, 11, 227-239. DOI: 10.11649/cs.2011.014. 
Violetta Koseska-Toszewa, Gramatyka konfrontatywna języków polskiego i bułgarskiego. Lingvaria, 11, 27-39.

\section{0}

Violetta Koseska-Toszewa \& A. Mazurkiewicz, Constructing Catalogue of Temporal Situations. Cognitive Studies |Etudes cognitives, 10, 71-109. DOI: $10.11649 /$ cs.2010.004.

Violetta Koseska-Toszewa \& Antoni Mazurkiewicz, Time flow and Tenses, Slawistyczny Ośrodek Wydawniczy, 2010, ss. 223.

Violetta Koseska-Toszewa, Form, its Meaning, and Dictionary Entries. Cognitive Studies | Études cognitives, 10, 133-143. DOI: 10.11649/cs.2010.008.

Ludmila Dimitrova, Violetta Koseska-Toszewa, Danuta Roszko \& Roman Roszko, Application of Multilingual Corpus in Contrastive Studies (on the example of the Bulgarian-Polish-Lithuanian Parallel Corpus). Cognitive Studies Études cognitives, 10, 217-239. DOI: 10.11649/cs.2010.013.

Ludmila Dimitrova, Violetta Koseska-Toszewa, Radovan Garabík, Tomaž Erjavec, Leonid Iomdin \& Volodymyr Shyrokov, MONDILEX - Towards the Research Infrastructure for Digital Resources in Slavic Lexicography, Cognitive Studies | Études cognitives, 10, 147-162. DOI: 10.11649/cs.2010.009.

Violetta Koseska-Toszewa \& Antoni Mazurkiewicz, Constructing Catalogue of Temporal Situations, Cognitive Studies | Études cognitives, 10, 71-109. DOI: $10.11649 / \mathrm{cs} .2010 .004$.

Violetta Koseska-Toszewa, Wielotomowa gramatyka konfrontatywna języka bułgarskiego i polskiego. Slavia Meridionalis, 10, 151-167.

Violetta Koseska-Toszewa \& Antoni Mazurkiewicz, Future and Possibility. W Tomaž Erjavec (Ed.), Research Infrastructure for Digital Lexicography. MONDILEX Fifth Open Workshop. Ljubljana, Slovenia, October 14-15, 2009, Proceedings of the 12th International Multiconference Information Society 2009, Department of Knowledge Technologies, Jožef Stefan Institute, Ljubljana, 72-86.

Violetta Koseska-Toszewa \& Antoni Mazurkiewicz, Net-Based Description of Modality in Natural Language (on the Example of Conditional Modality), Cognitive Studies $\mid$ Études cognitives, 9, 65-78.

Ludmila Dimitrova, Violetta Koseska-Toszewa, Danuta Roszko \& Roman Roszko, Bulgarian-Polish-Lithuanian Corpus - Problems of Development and Annotation. W Tomaž Erjavec (Ed.), Research Infrastructure for Digital Lexicography. MONDILEX Fifth Open Workshop. Ljubljana, Slovenia, October 14-15, 2009, Proceedings of the 12th International Multiconference Information Society 2009, Department of Knowledge Technologies, Jožef Stefan Institute, Ljubljana, 72-76.

Violetta Koseska-Toszewa, Form, Its Meaning, and Dictionary Entry. W Radovan Garabík (Ed.), Metalanguage and Encoding Scheme Design for Digital Lexicography. MONDILEX Third Open Workshop, Bratislava, Slovakia, 
15-16 April, 2009. Proceedings, L'.Štúr Institute of Linguistics. Slovak Academy of Sciences, Bratislava, 112-118.

Violetta Koseska-Toszewa \& Korytkowska Małgorzata, Polsko-bułgarska gramatyka konfrontatywna. W Violetta Koseska-Toszewa \& Roman Roszko (Eds.) Semantyka a konfrontacja językowa, 4, Slawistyczny Ośrodek Wydawniczy, Warszawa, 9-28.

Ludmila Dimitrova \& Violetta Koseska-Toszewa, Bulgarian-Polish Corpus. Cognitive Studies | Études cognitives, 9, 133-141.

Ludmila Dimitrova \& Violetta Koseska-Toszewa, Classifiers and Digital Dictionaries, Cognitive Studies | Études cognitives, 9, 117-131.

Ludmila Dimitrova, Violetta Koseska-Toszewa, Danuta Roszko \& Roman Roszko, Bulgarian-Polish-Lithuanian Corpus - Current Development. W Cristina Vertan, Stelios Piperidis, Elena Paskaleva, Milena Slavcheva (Eds.), International Workshop. Multilingual Resources, Technologies and Evaluation for Central and Eastern European Languages held in conjunction with The International conference RANLP - 2009, Proceedings, Borovets, 1-8.

Ludmila Dimitrova, Violetta Koseska-Toszewa, Ivan Derzhanski \& Roman Roszko, Annotation of Parallel Corpora (on the Example of the Bulgarian-Polish Parallel Corpus. W Volodymyr Shyrokov, Ludmila Dimitrova (Eds.). Organization and Development of Digital Lexical Resources. MONDILEX second Open Workshop, Kyiv, Ukraine, 2-4 February, 2009. Proceedings, Ukrainian LinguaInformation Fund, National Academy of Sciences of Ukraine, Kyiv, 47-54.

Ludmila Dimitrova, Violetta Koseska-Toszewa \& Joanna Satoła-Staśkowiak, Towards a Unification of the Classifiers in Dictionary Entries. W Radovan Garabík (Ed.), Metalanguage and Encoding Scheme Design for Digital Lexicography. MONDILEX Third Open Workshop, Bratislava, Slovakia, 15-16 April, 2009. Proceedings, L'.Štúr Institute of Linguistics. Slovak Academy of Sciences, Bratislava, 48-58.

Ludmila Dimitrova \& Violetta Koseska-Toszewa, The Significance of Entry Classifiers in Digital Dictionaries. W Lexicographic tools and techniques, Mondilex first open workshop, Moscow, Russia, 3-4 October, 2008, Proceedings, Moscow, 89-97.

Violetta Koseska-Toszewa, Many-Volume Contrastive Grammar of Bulgarian and Polish. Opera Slavica, Slavisticke rozhledy, XIX(2), 36-44.

Violetta Koseska-Toszewa, Many-volume Contrastive Grammar of Bulgarian and Polish, W Volodymyr Shyrokov \& Ludmila Dimitrova (Eds.), Organization and Development of Digital Lexical Resources. MONDILEX second Open Workshop, Kyiv, Ukraine, 2-4 February, 2009. Proceedings, Ukrainian Lingua-Information Fund, National Academy of Sciences of Ukraine, Kyiv, 88-97.

Виолетта Косеска-Тошева, Многотомна съпоставителна граматика на български език. Български език, 1, 5-19.

Violetta Koseska-Toszewa, Małgorzata Korytkowska \& Roman Roszko, Contrastive Studies and Semantic Interlanguage. Cognitive Studies $\mid$ Études cognitives, 9, 15-34. 
Violetta Koseska-Toszewa \& Roman Roszko, Remarks on Classification of Parts of Speech and Classifiers in an Electronic Dictionary. W Lexicographic tools and techniques, Mondilex first open workshop, Moscow, Russia, 3-4 October, 2008, Proceedings, Moscow, 80-88.

Violetta Koseska-Toszewa \& Roman Roszko, Semantic Interlanguage and Contrastive Studies. W Violetta Koseska-Toszewa, Ludmila Dimitrova \& Roman Roszko (Eds.), Representing Semantics in Digital Lexicography. Innovative Solutions for Lexical Entry Content in Slavic Lexicography. MONDILEX Fourth Open Workshop. Warszawa, Poland, 29 June - 1 July, 2009. Proceedings, Institute of Slavic Studies, Polish Academy of Sciences, Warsaw, 7-15.

Violetta Koseska-Toszewa \& Roman Roszko, Wstęp. W Violetta Koseska-Toszewa \& Roman Roszko, Semantyka a konfrontacja językowa (Eds.). T. 4, SOW, Warszawa, 7-9.

Ludmila Dimitrova, Violetta Koseska-Toszewa \& Volodymyr Shyrokov (Eds.), Organization and Development of Digital Lexical Resources. W MONDILEX second Open Workshop, Kyiv, Ukraine, 2-4 February, 2009. Proceedings, Ukrainian LinguaInformation Fund, National Academy of Sciences of Ukraine, Kyiv, 98-105.

\section{8}

Violetta Koseska-Toszewa \& Roman Roszko, Remarks on Classification of Parts of Speech and Classifiers in an Electronic Dictionary. W Lexicographic tools and techniques, Mondilex first open workshop, Moscow, Russia, 3-4 October, 2008, Proceedings - Moscow, 80-88.

Violetta Koseska-Toszewa, O syntezie Gramatyki konfrontatywnej bułgarsko-polskiej. Biuletyn Polskiego Towarzystwa Językoznawczego, 64, 185-194.

Violetta Koseska-Toszewa, Once More about the Functional Perspective of Sentences (Thematic - Rhematic Structure). Studia Kognitywne, 8, 109-117.

Violetta Koseska-Toszewa \& Natalia Kotsyba, What is Imperceptive Modality? Studia Kognitywne, 8, 139-159.

Ludmila Dimitrowa \& Violetta Koseska-Toszewa, Some problems in Multilingual Digital Dictioners. Studia Kognitywne, 8, 237-254.

Виолетта Косеска-Тошева, Многотомна българско-полска съпоставителна граматика. Български език, 56 (1), 5-18.

2007

Violetta Koseska-Toszewa, Małgorzata Korytkowska \& Roman Roszko, Polsko-butgarska gramatyka konfrontatywna, Wydawnictwo Akademickie „Dialog", Warszawa, ss. 530.

Violetta Koseska-Toszewa, Truth, Falsity and Incompletely Articulated Quantification (as exemplified by Polish and Bulgarian). Studia Kognitywne, 7, 105-114. 
Violetta Koseska-Toszewa, Gramatyka konfrontatywna butgarsko-polska. T. 7. Semantyczna kategoria czasu, Warszawa, ss. 210.

Violetta Koseska-Toszewa, Sieci Petriego i czas przyszły. W Od fonemu do tekstu: prace dedykowane profesorowi Romanowi Laskowskiemu, Kraków, 257-266.

\section{5}

Violetta Koseska-Toszewa, A. Mazurkiewicz, Once more about net representation of the semantic category of tense. Studia Kognitywne, 6, 63-81.

Violetta Koseska-Toszewa, About net description of conditional modality. Studia Kognitywne, 6, 91-97.

Violetta Koseska-Toszewa, Z dziejów badań nad synchronią języka. Studia z Filologii Polskiej i Słowiańskiej, 40, 165-174.

Violetta Koseska-Toszewa \& Antoni Mazurkiewicz, Once More about Net Representation of the Semantic Category of Tense. Studia Kognitywne, 6, 63-80.

Violetta Koseska-Toszewa, About Net Description of Conditional Modality. Studia Kognitywne, 6, 91-96.

Violetta Koseska-Toszewa, Bułgarskie formy werbalne a ich znaczenie temporalne i werbalne. Studia z Filologii Polskiej i Stowiańskiej, 39, 229-250.

2003

Violetta Koseska-Toszewa, Quantification of time, or of aspect? Studia Kognitywne, 5, 71-76.

Violetta Koseska-Toszewa, Les pièges de l'imparfait bulgare. Studia Kognitywne, 5, 115-122.

2002

Violetta Koseska-Toszewa, O związkach aspektu i czasu (na przykładzie gwar bułgarskich i języka literackiego). Studia z Filologii Polskiej i Słowiańskiej, 37, 189-201.

Violetta Koseska-Toszewa, Kwantyfikacja czasu, aspektu, czy czasu i aspektu? - PSS, Warszawa 2002, Tom do Kongresu Slawistów, Warszawa 2002, 109-115.

Виолетта Косеска-Тошева, Квантификация и естественный язык. W Коммуникативно-смысловые параметры грамматики и текста, Москва, 78-84.

Виолетта Косеска-Тошева, Функциите на формите на перфекта в българските диалекти. W Българският език през XX век, том посветен на Cm. Стойков, София, 130-138. 
Violetta Koseska-Toszewa, Bulgarian perfectum and its temporal and modal meanings. Studia Kognitywne, 4, 131-139.

Violetta Koseska-Toszewa, Can we talk about tense without talking about aspect at the same time? Studia Kognitywne, 4, 87-92.

Виолетта Косеска-Тошева, Върху някои проблеми на когнитивната граматика и семантичния език-посредник. W Традищия и съвременност в българския език, София, 297-301.

Violetta Koseska-Toszewa, O związkach aspektu i czasu (na przykładzie gwar bułgarskich i języka literackiego). Studia z Filologii Polskiej i Stowiańskiej, 37, 189-201.

\section{0}

Виолетта Косеска-Тошева, Пак върху теорията на квантификация в български и полски. Български език, 48 (2), 57-59.

Violetta Koseska-Toszewa, Никога не / nigdy nie. W Лексикографски и лексиколожки четения'98, София, 30-34.

1999

Violetta Koseska-Toszewa, O wieloznaczności wyrażeń kwantyfikujących w języku bułgarskim i polskim. Prace Filologiczne, 44, 313-318.

Violetta Koseska-Toszewa, O stanie/zdarzeniu w świetle pewnych struktur słowotwórczych, W Актуални проблеми на българското словообразуване, $148-154$.

Violetta Koseska-Toszewa, On Quantification in Natural Language. W Studia Kognitywne. T. 3, 83-99.

Violetta Koseska-Toszewa, About Time, Aspect and Quantification in Bulgarian and Polish. W Studia Kognitywne. T. 3, 99-111.

Violetta Koseska-Toszewa, Does a Proper Name in the Logical Sense Exist in a Natural Language? W Semantyka a konfrontacja językowa 2, SOW, 31-36.

1998

Violetta Koseska-Toszewa, Kontrastywna (konfrontatywna) lingwistyka i typologia. W Z Polskich Studiów Slawistycznych. Seria 9 Językoznawstwa, Warszawa, 147-152.

Виолетта Косеска-Тошева, Из проблематиката на сьпоставителното езикознание и типология. Съпоставително езикознание, 24 (2-3), 34-42.

1997

Виолетта Косеска-Тошева, Квантификация и вид. W Семантика и структура словянского вида, II, Kraków, 141-147. 
Violetta Koseska-Toszewa, Gramatyka bułgarsko-polska - semantyczna gramatyka konfrontatywna. W Symbolae slavisticae. Dedykowane pani profesor Hannie Popowskiej-Taborskiej, Warszawa.

Violetta Koseska-Toszewa, O gramatyce konfrontatywnej bułgarsko-polskiej. Modalność, t. 6. W Общңност и многообразие на славянските езищи, София, 91-97.

Violetta Koseska-Toszewa, Antoni Mazurkiewicz, Réseaux non-déterministes et cycliques dans la description des phénomènes temporels dans les langues naturelles. W Studia kognitywne. T. 2, SOW, Warszawa, 71-94.

\section{6}

Violetta Koseska-Toszewa, Българско-полска семантична сьпоставителна граматика. Съпоставително езикознание, 21 (2), 25-31.

1995

Violetta Koseska-Toszewa, Vyara Maldžieva \& Jordan Penčev, Gramatyka konfrontatywna butgarsko-polska. T. 6, cz. 1. Modalność. Teoretyczne problemy opisu, Warszawa, ss. 201.

Violetta Koseska-Toszewa, O aspekcie i czasie w ujęciu kognitywnym. Biuletyn Polskiego Towarzystwa Językoznawczego, 51, 25-31.

1994

Violetta Koseska-Toszewa \& Antoni Mazurkiewicz, Les réseaux de Petri et la description de la temporalité et de la modalité dans les langues naturelles. W Studia kognitywne. T. 1. Warszawa, 89-112.

1993

Violetta Koseska-Toszewa, De l'explication incomplète de la quantification dans l'énconcé bulgare at polonais. W Complétude et incomplétude dans les langues romanes et slaves: actes du VI Colloque international de linguistique romane et slave, Cracovie, 149-160.

Violetta Koseska-Toszewa, Gramatyka konfrontatywna rosyjsko-polska: sktadnia, Warszawa, ss. 186.

Violetta Koseska-Toszewa, O stanie/zdarzeniu w świetle pewnych faktów słowotwórczych. W Studia gramatyczne bułgarsko-polskie. T. 5-6. Konfrontacja językowa. Stowotwórstwo. Wybrane kategorie semantyczne, Warszawa, 51-58.

Violetta Koseska-Toszewa, Sieciowy opis warunkowości w języku naturalnym. W Językoznawstwo synchroniczne i diachroniczne, Warszawa, 178-187.

Violetta Koseska-Toszewa, Małgorzata Korytkowska, Z problematyki modalności imperceptywnej. W Studia gramatyczne butgarsko-polskie. T. 5-6. Konfrontacja językowa. Stowotwórstwo. Wybrane kategorie semantyczne, Warszawa, 177-191. 
1992

Виолетта Косеска-Тошева, О проблемах описания категории темпоральности в болгарско-польской конфронтативной грамматике. W Synchroniczne badania porównawcze systemów języków słowiańskich, Warszawa.

Violetta Koseska-Toszewa, O nakładaniu się różnych struktur semantyczno-logicznych (na przykładzie języka bułgarskiego). W Procesy rozwojowe w językach stowiańskich, Warszawa, 77-84.

Violetta Koseska-Toszewa \& Małgorzata Korytkowska, Z problematyki konfrontatywnego opisu warunkowości i imperceptywności (na przykładzie języka bułgarskiego i polskiego). W Z polskich studiów slawistycznych. Seria 8. Jęzkoznawstwo, 107-117.

\section{1}

Violetta Koseska-Toszewa, O języku pośredniku i badaniach konfrontatywnych. W Problemy teoretyczno-metodologiczne badań konfrontatywnych języków słowiańskich, Warszawa.

Виолетта Косеска-Тошева \& Георги Гаргов, Българско-полска съпоставителна граматика, т. 2. Семантичната категорич определеност/ неопределеност, София.

Виолетта Косеска-Тошева, За езика-посредник и сьпоставителните изследвания. Съпоставително езикознание, 16 (1), 29-37.

Violetta Koseska-Toszewa \& Georgi Gargov, Kwantyfikacja, temporalność, modalność. W Studia gramatyczne bułgarsko-polskie. T. 4. Modalność a inne kategorie językowe. Wrocław.

Violetta Koseska-Toszewa \& Antoni Mazurkiewicz, Sieciowe przedstawienie temporalności i modalności w zdaniach języka naturalnego. W Studia gramatyczne butgarsko-polskie. T. 4. Modalność a inne kategorie językowe, Wrocław, 7-25.

1990

Виолетта Косеска-Тошева, За вербалните и адвербиалните форми и кванторните им значения в българския и полския език. Български език, 40 (3), 199-205.

Violetta Koseska-Toszewa, Jeszcze raz o bułgarskim imam. W Językowe studia batkanistyczne. T. 2. Warszawa, 79-85.

Violetta Koseska-Toszewa, O języku pośredniku i badaniach konfrontatywnych. W Problemy teoretyczno-metodologiczne badań konfrontatywnych języków stowiańskich. Warszawa, 17-19.

Violetta Koseska-Toszewa \& Georgi Gargov, O bułgarskim nikoga i jego odpowiedniku w polskim. W Studia linguistica memoriae Zdislai Stieber dedicata. Wrocław, 171-180. 


\section{8}

Виолетта Косеска-Тошева, О кванторной модели описания некоторых семантических категорий в болгарском, польском и русском языках. Z Polskich Studiów Slawistycznych. Seria 7. Językoznawstwo, 199-205.

Violetta Koseska-Toszewa, Antoni Mazurkiewicz, Net Representation of Sentences in Natural Languages. W Advances in Petri Nets. Lecture Notes in Computer Science, 340, Berlin: Springer-Verlag, 249-266.

\section{7}

Violetta Koseska-Toszewa, O pewnych strukturach logiczno-semantycznych i ich odpowiednikach w języku polskim i bułgarskim. W Slawistyczne studia językoznawcze. Wrocław, 149-153.

Violetta Koseska-Toszewa, O pewnym kwantyfikacyjnym modelu opisu językowej kategorii określoności/nieokreśloności. W Studia gramatyczne butgarsko-polskie. T. 2: Określoność/nieokreśloność. Wrocław, 65-82.

Violetta Koseska-Toszewa, Tadeusz Szymański (rec.), Z. Topolińska, B. Vidoeski. Polski - macedoński. Gramatyka konfrontatywna (zarys problematyki). Z. 1, Wprowadzenie, Wrocław, ss. 130. Studia z Filologii Polskiej i Słowiańskiej, 24, 291-312.

\section{6}

Violetta Koseska-Toszewa, Kategoria określoności/nieokreśloności a kwantyfikacja na gruncie języka naturalnego. W Od kodu do kodu. Prace ofiarowane profesorowi Olgierdowi Adrianowi Wojtasiewiczowi na 70-lecie jego urodzin, Warszawa, 43-51.

Виолетта Косеска-Тошева, О кванторной модели описания некоторых семантических категорий в болгарском, польском и русском языках. W II международен конгрес по българистика. Т. 3. Доклади, София, 401-409.

Violetta Koseska-Toszewa, De l'emploi de l'article en langue bulgare, en comparaison avec d'autres langues balkaniques. W Językowe studia batkanistyczne, T. 1, Wrocław, 17-25.

Violetta Koseska-Toszewa, O pewnym typie gramatyki konfrontatywnej na przykładzie gramatyki bułgarsko-polskiej. W Typy opisów gramatycznych języków, Wrocław, 15-23.

Violetta Koseska-Toszewa, O temporalności inaczej. W Studia gramatyczne bułgarsko-polskie, T. 1, Temporalność, Wrocław, 39-96.

\section{5}

Violetta Koseska-Toszewa, Jak rozgraniczyć użycie aorystu od niedokonanych od użycia imperfectum od niedokonanych. Studia z Filologii Polskiej i Słowiańskiej, 23, 195-201. 
1984

Violetta Koseska-Toszewa, Jolanta Mindak, O dwóch kategoriach modalnych w bułgarskim, polskim i serbskochorwackim. W Studia konfrontatywne polsko-poludniowostowiańskie, Warszawa, 75-102.

Violetta Koseska-Toszewa, Jolanta Mindak, O modalności jako kategorii pojęciowej. Studia z Filologii Polskiej i Stowiańskiej, 22, 105-109.

Violetta Koseska-Toszewa, O określoności w bułgarskim i polskim. W Studia konfrontatywne polsko-południowostowiańskie, Wrocław, 39-53.

1983

Виолетта Косеска-Тошева, Върху някои проблеми на категорията определеност-неопределеност в български и полски. W Първи международен конгрес по българистика, София 23 май - 3 юни 1981. Доклади. Исторически развой на българския език I. Сравнително езикознание. Диалектология. София, 72-76.

Виолетта Косеска-Тошева, Семантична интерпретация на проблеми свързани с категорията определеност-неопределеност (върху материал от българския и полския език). Съпоставително езикознание, 8 (5), 21-27.

Violetta Koseska-Toszewa, Konstrukcje z polskim mieć i bułgarskim imam. W Studia linguistica memoriae Zdislai Stieber dedicata, Wrocław, 137-143.

Violetta Koseska-Toszewa, O kategorii określoności-nieokreśloności w planie konfrontatywnym (na przykładzie z języka bułgarskiego, polskiego i rosyjskiego). Z polskich studiów slawistycznych. Seria 6. Językoznawstwo, 187-194.

Violetta Koseska-Toszewa, Uwagi na temat użycia rodzajnika bułgarskiego. W Trzynaście wieków Bułgarii. Тринадесет века България, Wrocław, 73-78.

1982

Violetta Koseska-Toszewa, Semantyczne aspekty kategorii określoności-nieokreśloności (na materiale z języka bułgarskiego, polskiego i rosyjskiego). Wrocław, ss. 88.

1981

Виолетта Косеска-Тошева, Върху семантичните аспекти на категорията определеност-неопределеност в български и полски. W Материали от III комплексна конференция по българистика, София.

Violetta Koseska-Toszewa, Predykacja imienna w języku bułgarskim w zestawieniu z polskim. W Janusz Siatkowski (Ed.), Zagadnienia predykacji imiennej w językach południowostowiańskich, Wrocław, 8-10.

Violetta Koseska-Toszewa, Uwagi na temat optativu w bułgarskim, polskim i rosyjskim. Studia z Filologii Polskiej i Stowiańskiej, 20, 29-134. 
Violetta Koseska-Toszewa, Czy istnieje zdanie egzystencjalne w języku naturalnym? W Studia gramatyczne 5, Wrocław, 47-51.

1980

Виолетта Косеска-Тошева, Категория определеност-неопределеност като „понятийна категория“. Език и литература, 35 (3), 33-42.

Violetta Koseska-Toszewa, Ze studiów nad modalnością (na przykładzie języków bułgarskiego, rosyjskiego i polskiego). Studia z Filologii Polskiej i Stowiańskiej, 19, 143-151.

1979

Violetta Koseska-Toszewa, Категория модальности в реляции с категорией определенности (на материале русского, болгарского и польского языков). Slavia Orientalis, 28 (2), 273-277.

Violetta Koseska-Toszewa, Отново по въпроса за екзистенциалните изречения. Съпоставително езикознание, 4 (3), 11-17.

Violetta Koseska-Toszewa, Informacja o określoności we frazie werbalnej i nominalnej języka bułgarskiego, polskiego i rosyjskiego. Otázky slovanské syntaxe, 4 (1), 203-212.

Violetta Koseska-Toszewa, O trybie warunkowym i zdaniu warunkowym w złożonym zdaniu bułgarskim. Studia z Filologii Polskiej i Stowiańskiej, 18, 193-200.

1978

Виолетта Косеска-Тошева, Вербална форма, темпорална функция, темпорално значение. Език и литература, 32 (1), 23-27.

Виолетта Косеска-Тошева, За темпоралните системи в български език и някои от неговите диалекти. Български език, 28 (4), 326-333.

Казимеж Фелешко, Виолетта Косеска-Тошева, Ирена Савицка, Система южнославянских претеритальных категорий в сопоставлении с польским. Z polskich studiów slawistycznych. Seria 5. Językoznawstwo, 393-402.

Violetta Koseska-Toszewa, Informacja o określoności we frazie werbalnej i nominalnej języka bułgarskiego, polskiego i rosyjskiego. Slavia Orientalis, 27 (2), 259-265.

Violetta Koseska-Toszewa, Relacje modus - tempus w języku bułgarskim na tle języka polskiego. Studia z Filologii Polskiej i Stowiańskiej, 17, 289-298.

1977

Violetta Koseska-Toszewa, System temporalny gwar butgarskich na tle języka literackiego, Wrocław, ss. 154.

Violetta Koseska-Toszewa, Conditionalis a zdanie warunkowe w języku bułgarskim (na tle języka polskiego). W Kategorie werbalne $w$ języku polskim i butgarskim, Warszawa, 51-56. 
Violetta Koseska-Toszewa, Formy aorystu i imperfectum w zdaniu podrzędnym w języku bułgarskim. Studia z Filologii Polskiej i Słowiańskiej, 16, 229-238.

Kazimierz Feleszko, Violetta Koseska-Toszewa, Południowosłowiański aoryst i imperfectum w zdaniach podrzędnych. Studia z Filologii Polskiej $i$ Stowiańskiej, 16, 225-228.

Violetta Koseska-Toszewa, Problematyka conditionalis w ujęciu semantyczno-syntaktycznym. W Заседание на Комисията за анализ на граматичните структури на славянските езици при Международния комитет на славистите (Предварителни материали). Т. 2, София, 36-47.

1976

Виолетта Косеска-Тошева, Некоторые проблемы актуализации в болгарском, польском и русском предложении. W МАПРЯЛ. Основные доклады польской делегаиии, Wrocław, 209-217.

Виолетта Косеска-Тошева, Является ли имперцептивная модальность турцизмом в болгарском языке? Rocznik Slawistyczny, 37 (1), 13-17.

Violetta Koseska-Toszewa, Formy aorystu i imperfectum w zdaniu podrzędnym czasowym w języku bułgarskim. Studia z Filologii Polskiej i Słowiańskiej, $15,185-197$.

Violetta Koseska-Toszewa, Informacja o określoności w znaczeniach temporalnych form werbalnych w języku polskim i bułgarskim. Бюлетин за съпоставително изследване на българския език с други езици. 1/2, 45-56.

1975

Виолетта Косеска-Тошева, Турцизъм ли е имперцептивната модалност в български език? Език и литература, 30 (4), 71-74.

Violetta Koseska-Toszewa, Forma werbalna a jej funkcja temporalna (na przykładach form praesens w języku polskim, rosyjskim i bułgarskim). W Charakterystyka temporalna wypowiedzenia, Wrocław, 159-165.

Violetta Koseska-Toszewa, O pewnych formach imperceptywnych w gwarach bułgarskich. Rocznik Slawistyczny, 35 (1), 35-39.

Violetta Koseska-Toszewa, Temporalne i modalne użycie form perfectum w języku bułgarskim. Studia z Filologii Polskiej i Słowiańskiej, 13, 157-169.

Violetta Koseska-Toszewa, Z problematyki temporalno-aspektowej w języku bułgarskim. (Relacja imperfectum - aoryst). Studia z Filologii Polskiej i Stowiańskiej, 14, 213-226.

Kazimierz Feleszko, Violetta Koseska-Toszewa, Irena Sawicka, Związki aspektu z temporalnością w językach południowosłowiańskich. Studia z Filologii Polskiej i Stowiańskiej, 14, 183-187. 
1973

Виолетта Косеска-Тошева, Някои лексикални и словообразувателни особености на българските диалекти в сравнение с другите славянски езици. Език и литература, 28, (2), 36-44.

Violetta Koseska-Toszewa, Uwagi o wymowie psł. * ${ }_{e}$ w gwarach zachodniobułgarskich (na tle języków południowosłowiańskich). Rocznik Slawistyczny, 34 (1), 55-60.

Kazimierz Feleszko, Violetta Koseska-Toszewa, Z problematyki czasownika południowosłowiańskiego. Studia z Filologii Polskiej i Stowiańskiej, 13, 141-144.

1972

Violetta Koseska-Toszewa, Atrybutywne funkcje niektórych części mowy a tzw. kategoria określoności w języku bułgarskim. Rocznik Slawistyczny, 33 (1), 27-31.

Violetta Koseska-Toszewa, Bułgarskie słownictwo meteorologiczne na tle ogólnosłowiańskim, Wrocław, pp. 134 (wraz z 30 mapami).

Violetta Koseska-Toszewa, System temporalny północno-zachodniej gwary bułgarskiej na tle języka literackiego. Studia z Filologii Polskiej i Stowiańskiej, $12,233-245$.

1971

Violetta Koseska-Toszewa, Próba analizy słowotwórczej bułgarskich nazw wiatrów. Studia z Filologii Polskiej i Słowiańskiej, 10, 205-212.

1970

Violetta Koseska-Toszewa, O pewnych gwarowych podziałach Bułgarii w świetle współczesnych bułgarskich nazw miejscowych. Studia z Filologii Polskiej i Słowiańskiej, 9, 225-233.

Violetta Koseska-Toszewa, Uwagi o tzw. kategorii określoności (na materiale języka bułgarskiego i rosyjskiego). Rocznik Slawistyczny, 31 (1), 39-44.

1969

Violetta Koseska-Toszewa, Personifikacja i prawo tabu w bułgarskich nazwach ruchu powietrza, Studia z Filologii Polskiej i Stowiańskiej, 8, 201-207.

1968

Violetta Koseska-Toszewa, Poprax, popraxa w języku bułgarskim. Studia z Filologii Polskiej i Stowiańskiej, 7, 218-219. 